\title{
Lung research funding in the UK: the British Lung Foundation perspective
}

\author{
W MacNee, I M Walden
}

The British Lung Foundation was launched in 1985 by a group of leading respiratory specialists to fund medical research into the prevention, treatment, alleviation, and cure of all lung diseases and to disseminate the useful results of this research. It remains the only charity supporting research throughout the UK into all aspects of lung disease and relies entirely on voluntary donations for this.

Although lung disease is the second largest cause of mortality in the UK, accounting for one in five deaths, its research funding attracts only $2 \%$ of government funding. The demand placed on the British Lung Foundation for research funding is substantial and is increasing every year.

Since 1985 the British Lung Foundation has committed over $£ 10.8$ million to research across the whole spectrum of lung diseases. These funds have been raised against strong competition for voluntary donations from other charitable causes, many of which are considered more fashionable and high profile. In terms of fund raising, lung disease is largely unseen. Despite these constraints, the Foundation is proud to have played a part in funding many research projects which have led to major advancements in the understanding and treatment of lung diseases. These include investigating signal transduction mechanisms in small cell lung cancer, ${ }^{1}$ understanding oxidative stress responses and redox signalling in acute lung injury patients, ${ }^{2}$ developing an accurate technique for monitoring lung inflammation by exhaled NO measurements, ${ }^{3}$ understanding the role of collectins in host defences, ${ }^{4}$ developing a synthetic vaccine against respiratory syncytial virus infection, ${ }^{5}$ studying the association of the $\alpha_{1}$-antitrypsin gene with chronic lung disease,${ }^{6}$ investigating new methods for the preservation of lung tissue to improve storage in transplantation, ${ }^{7}$ evaluating CPAP therapy for patients with mild sleep apnoea/hypopnoea syndrome, ${ }^{8}$ and assessing new approaches to measuring airway function in infants. ${ }^{9}$

This year the Foundation's Scientific Committee handled 110 requests for new grants totalling $£ 7$ million. With $£ 1.1$ million to allocate, the Committee had a very difficult task in selecting which grants to award; $85 \%$ of the total number of applications and $70 \%$ of those sent to external referees had to be turned down, although many were thought worthy of support if funds had been available. The Foundation fully appreciates the considerable work involved for the applicants, assessors and Committee members in its grant round and much regrets that the majority will have to be turned away.

The British Lung Foundation's Executive Committee has recently reviewed the Foundation's overall strategy. This commits the charity to a major national campaign to raise public awareness, increase its income, and double the amount available for research by the year 2001 .

The research currently funded by the British Lung Foundation and the criteria that guided the selection process have also been reviewed. Recent policy changes at the Medical Research Council, the need to attract corporate and trust donors, and the increasing numbers of grant applications received have been taken into account. The resulting strategy is to be reviewed annually by the Scientific Committee to reflect changes and developments in the respiratory field.

The Committee's overriding criteria for making grants remain that the project must be of the highest standard of scientific excellence in terms of the quality of the research team, the objectives of the research and the prospects of achieving them, and must be of unequivocal relevance to the respiratory system. The strategy also seeks to be more focused.

Recognising the difficulty of focusing on only some lung diseases, and the need to encourage some "blue skies" projects, the strategy calls for a balance, as far as possible, and subject to the overriding criterion of scientific excellence between clinical research, laboratory research, and epidemiological/other research.

The amount of resources expended on lung cancer, asthma, and cystic fibrosis by other charities is currently more than the British Lung Foundation's total annual budget for all research. While still recognising the importance of funding research in all lung diseases, the Foundation will seek a collaborative approach to these specific areas subject to very clear agreements with its sister charities.

Finally, the strategy notes the promotional value of having British Lung Foundation funded research projects spread across its six branch regions. This will, however, depend on the quality, category, and number of applications.

With the transfer of trusteeship of the charity from the Council of Management to the Executive Committee, the Scientific Committee now answers to the Executive, reporting and providing scientific advice. The importance of its wider role has been reflected in the change of title from Grants Committee to Scientific Committee.

To enable it to embrace a wider area of expertise and reflect the size of the respiratory field, membership of the Scientific Committee is to increase to 10 . For the first time a lay member will be included. The Committee is currently composed of a chairman, two clinician scientists, two respiratory physicians, one epidemiologist, one paediatrician, one laboratory-based scientist, and one infectious diseases specialist.

Recognising that much more still needs to be done in the fight against lung disease, the British Lung Foundation has ambitions to be a much larger player in lung research. The charity is committed to a period of significant growth, aiming to increase the sum available for research to at least $£ 3$ million by the year 2001. This is a challenging time for the Foundation and an exciting prospect for all concerned with respiratory medicine.

British Lung Foundation 78 Hatton Garden,

London EC1N 8fR, UK

W MACNEE I M WALDEN

1 Sethi T, Langdon S, Smyth J, et al. Growth of small cell lung cancer cells: stimulation by multiple neuropeptides and inhibition by broad spectrum antagonists in vitro and in vivo. Cancer Research (Suppl) 1992;52:2737s$42 \mathrm{~s}$. 
2 Quinlan GJ, Lamb NJ, Tilly R, et al. Plasma hypoxanthine levels in ARDS: implications for oxidative stress; morbidity and mortality. Am $\mathcal{F}$ Respir Crit Care Med 1997;155:479-84.

3 Kharitonov SA, Yates DH, Chung KF, et al. Changes in the dose of inhaled steroid affect exhaled nitric oxide levels in asthmatic patients. Eur Respir $\mathcal{F}$ 1996;9:196-201.

4 Malhotra R, Sim RB. Collectins and viral infection. Trends Microbiol 1995;3: 240-4.

5 Hsu S-C, Shaw DM, Steward MW. The induction of respiratory syncytial virus-specific cytotoxic T-cell responses following immunization with a synthetic peptide containing a fusion peptide linked to a cytotoxic $\mathrm{T}$ lymphocyte epitope. Immunology 1995;85:347-50.
6 Kalsheker N, Morgan $\mathrm{K}$. The $\alpha_{1}$ antitrypsin gene and chronic lung disease. Thorax 1990;45:759-64.

7 Pickford MA, Gower JD, Dore C, et al. Lipid peroxidation and ultrastructural changes in rat lung isografts after single-passage organ flush and 48-hour cold storage with and without one-hour reperfusion in vivo. Transplantation 1990;144:210-8.

8 Engleman HM, Martin SE, Deary IJ, et al. Effect of CPAP therapy on daytime function in patients with mild sleep apnoea/hypopnoea syndrome. Thorax 1997;52:114-9.

9 Dundas I, Dezateux CA, Fletcher ME, et al. Comparison of single-breath and plethysmographic measurements of resistance in infancy. Am f Respir Crit Care Med 1995;151:1451-8. 